\title{
Routine Cytological Staining Techniques
}




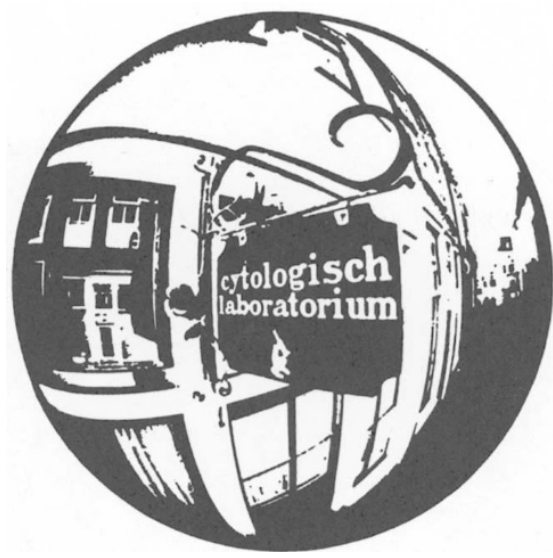




\section{Routine Cytological \\ Staining Techniques}

Theoretical Background and Practice

Mathilde E. Boon

and

Johanna S. Drijver

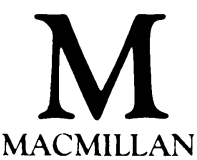


(C) Mathilde E. Boon and Johanna S. Drijver 1986

All rights reserved. No reproduction, copy or transmission of this publication may be made without written permission.

No paragraph of this publication may be reproduced, copied or transmitted save with written permission or in accordance with the provisions of the Copyright Act 1956 (as amended).

Any person who does any unauthorised act in relation to this publication may be liable to criminal prosecution and civil claims for damages.

First published 1986

Published by

MACMILLAN EDUCATION LTD

Houndmills, Basingstoke, Hampshire RG21 2XS

and London

Companies and representatives

throughout the world

Filmsetting by Vantage Photosetting Co. Ltd

Eastleigh and London

Printed in Hong Kong

British Library Cataloguing in Publication Data

Boon, Mathilde

Routine cytological staining techniques.

1. Stains and staining (Microscopy)

2. Cytology-Technique

I. Title II. Drijver, Johanna

578'.64 QH237

ISBN 978-0-333-39713-8

ISBN 978-1-349-18250-3 (eBook)

DOI 10.1007/978-1-349-18250-3 


\section{Contents}

Preface

\section{PART ONE}

\section{Chapter 1 Cell biology}

1.1 Nucleus

1.2 Cytoplasm

Chapter 2 Comparing cells in histology and cytology

2.1 Introduction

2.2 Cell changes occurring when cells are removed from tissues

2.3 Histological cutting versus cytological spreading

2.4 Changes in floating cells

2.5 Cell harvest in histology and cytology

2.6 Cell block technique

2.7 Staining results in histological versus cytological specimens

2.8 Resemblance of cells in histology and cytology

Chapter 3 Principles of staining and dyeing

3.1 Introduction

3.2 Staining

3.3 What makes a chemical compound a dye?

3.4 Classification of dyes

3.5 Other means of colouring

3.6 Staining with natural dyes: past and present

3.7 Mechanism of dyeing

3.8 Dyeing in cytology

3.9 Methods of dyeing

3.10 Progressive and regressive staining 
3.11 Differential dyeing

3.12 Influence of $\mathrm{pH}$ on dyeing proteins

\section{Chapter 4 Fixation}

4.1 Introduction

4.2 Requirements of a fixative $\quad 52$

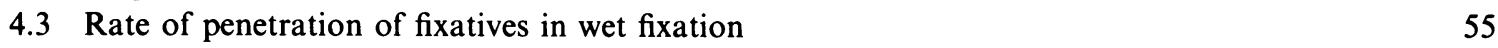

$\begin{array}{lll}4.4 & \text { Fixation by air drying } & 55\end{array}$

4.5 Fixation of cells in suspension and other preservation methods $\quad 56$

\begin{tabular}{ll}
4.6 & Polyethylene glycol in wet fixation techniques \\
\hline
\end{tabular}

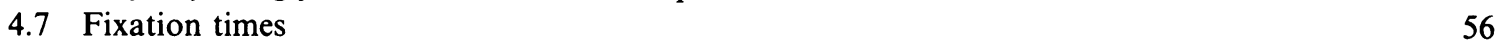

4.8 Fixatives: their reaction with cell components; their effect on some cell features and on staining results

Chapter 5 Nuclear dyes

5.1 General properties

5.2 General nuclear dyes: Haematoxylin

5.3 Other general nuclear dyes

5.4 Specific nuclear dyes

Chapter 6 Cytoplasmic dyes and stains

6.1 Introduction

6.2 Cytoplasmic dyes

6.3 Polychrome dyes

6.4 Histochemical staining methods

6.5 Staining pigments

6.6 Staining fibrous components

Chapter 7 Staining of the nucleolus

7.1 Introduction

7.2 Some nucleolar staining methods

7.3 Staining of nucleoli in the Papanicolaou methods

7.4 Staining of nucleoli in the Romanowsky-Giemsa methods

Chapter 8 Vital staining methods and quick stains

8.1 Introduction

8.2 Vital staining techniques

8.3 Quick staining techniques

Chapter 9 Neutral stains: the Romanowsky-Giemsa methods

9.1 Introduction

9.2 A short history of the development of the Romanowsky-Giemsa stains

9.3 Romanowsky-Giemsa stains in current use 
$\begin{array}{lll}\text { Chapter } 10 & \text { Preparing cytological slides } & 102\end{array}$

$\begin{array}{llr}10.1 & \text { Introduction } & 102\end{array}$

$\begin{array}{llr}10.2 & \text { Processing cytological materials } & 102\end{array}$

$\begin{array}{lll}10.3 & \text { Various slide preparation techniques } & 107\end{array}$

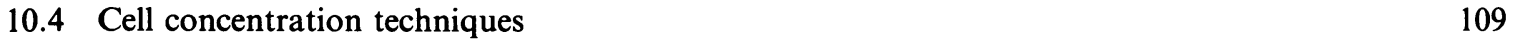

10.5 Cell blocking techniques 113

$\begin{array}{lll}10.6 & \text { Liquefying mucus and haemolysing blood } & 113\end{array}$

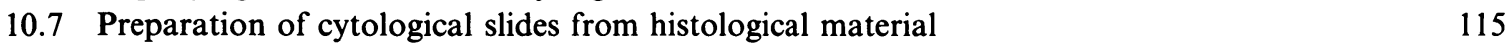

$\begin{array}{lll}10.8 & \text { Adhesives } & 116\end{array}$

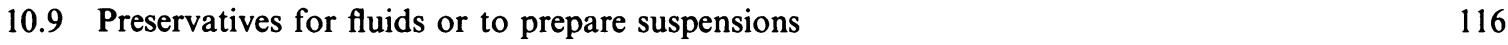

$\begin{array}{ll}10.10 \text { Fixatives } & 117\end{array}$

10.11 Various combinations of fixation and staining techniques 118

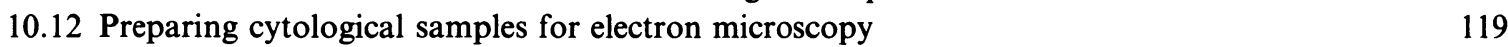

$\begin{array}{llr}\text { Appendix } 1 & \text { Fixatives } & 121\end{array}$

$\begin{array}{lll}\text { Appendix } 2 & \text { Staining methods } & 127\end{array}$

$\begin{array}{llr}\text { Appendix } 3 & \text { Staining solutions } & 149\end{array}$

$\begin{array}{llr}\text { Appendix } 4 & \text { Dyes } & 169\end{array}$

$\begin{array}{lr}\text { Recommended reading } & 194\end{array}$

$\begin{array}{ll}\text { References } & 195\end{array}$

$\begin{array}{lr}\text { Index } & 215\end{array}$

PART TWO: Atlas 


\section{Preface}

We had several reasons for writing this book and several goals in mind when we started our investigations into routine fixation and staining. Above all we wanted to know more about the mechanisms of the staining processes, and to gain an insight into the differences between staining cytological and histological material. We believe that the results of our research are of considerable assistance to anyone involved in routine cytological diagnosis, since the quality of the diagnosis depends on the quality of the smear. We do not consider immunotechniques and enzyme staining to be routine, so these methods are not discussed in our book.

We have learned that when the mechanisms of the staining processes are understood, one can manipulate the staining results according to one's wishes, and standardise the staining. Both goals are most easily reached if the staining solutions are prepared in the laboratory, a process that has proved to be easier than we had anticipated. This manual therefore contains details of methods for preparing staining and fixing solutions, together with practical advice on the most economical methods of staining and fixing.

We also discuss the interpretation of the staining results, and the need to be critical of unnecessary suboptimal results. We stress that cellular and nuclear dimensions in cytological slides are totally dependent on the cytopreparatory technique employed, and differ significantly from those in tissue sections.

The idea that the quality of the slide is of paramount importance for the success of cytodiagnosis was first realised by one of the authors (M.E.B.) when she was trained in the laboratory of Dr B. Naylor in Ann Arbor, Michigan, during the period 1967-68. In the following years, we noticed at various cytology congresses that many cytological diagnoses were made on sub-optimal slides, and the cytopathologists did not even know exactly how these were fixed and stained. In discussions we became aware that neither we nor our fellow cytologists knew exactly what component in the routine stain stained what in our slides. The explanations we found in cytology and histology books concerning staining cytological slides were not satisfactory for us. We therefore realised that we had to investigate for ourselves in order to find the right answers. Since we thought that knowledge concerning the components of the cell was a keystone in such investigations, we sought contact with the world of biology, and therefore this book is written by a cytologist and a biologist. The very satisfying contacts with other research workers in Europe, Japan and the USA have greatly influenced our insight into this complicated subject. When we had acquired a knowledge of staining mechanisms, we were able to exploit the staining techniques instead of suffering by them, and to profit from their use in our diagnostic work.

It should be clearly understood that our work is far from complete. We hope, however, that this book will enable readers to find the preparation and staining of cytological slides to be as exciting and satisfying as the authors do themselves. 


\section{Acknowledgements}

Many people have given us invaluable advice concerning this book. We thank them all, in particular the following.

Dr R.W. Horobin of the University of Sheffield, UK, read through the first draft of the book and gave us priceless constructive criticism. He also provided us with the data on the physical and chemical characteristics of the dyes, as published in this book. Professor Dr D. Wittekind of the University of Freiburg, West Germany, has shown from the beginning of our work a great interest in our book, and has shared with us the results of his own experiments with the Romanowsky-Giemsa staining method.

We are grateful for the beautiful scanning electron microscope pictures, which form an essential part of the book by showing the three-dimensional aspects of cells in smears. They were provided by Ms P.H.T. van der Zanden and Dr P. Kenemans from the division of gynaecological oncology, University of Nijmegen, The Netherlands.

Last but not least we want to thank the cytotechnologists of the Leiden Cytology Laboratory for their endurance when trying to do cytodiagnostic work on smears stained in all colours of the rainbow, and the cytotechnologists of the SSDZ in Delft for their co-operation in developing various cytopreparatory techniques.

The drawings in this book were made with great enthusiasm by B. Brest from the Technical University in Delft. The cover is based on the colours of stained cells in cytological slides. Our good friend Frans Rombouts, the artist who designed it, succeeded extremely well in demonstrating how beautiful staining can be. 